\title{
Indoor and outdoor investigation comparison of photovoltaic thermal solar air collector
}

\author{
Bahtiar $^{1}$, Muhammad Zohri ${ }^{2}$, Ahmad Fudholi ${ }^{3}$ \\ ${ }^{1,2}$ Department of Physics Education, Universitas Islam Negeri Mataram, Indonesia \\ ${ }^{2,3}$ Solar Energy Research Institute, the National University of Malaysia, Malaysia
}

\section{Article Info \\ Article history: \\ Received Dec 30, 2019 \\ Revised Feb 3, 2020 \\ Accepted Mar 23, 2020}

\section{Keywords:}

Air collector

Efficiency

Indoor

Outdoor

Photovoltaic thermal

\begin{abstract}
Photovoltaic technology is one of renewable energy technology very hopeful, especially photovoltaic thermal system or PVT system. A PVT system solar air collector produces hot air and electricity simultaneously. In this study, indoor and outdoor investigation comparison of PVT system solar air collector has tested at the National University of Malaysia. The indoor and outdoor investigation conducted with variation mass flow rates from $0.01 \mathrm{~kg} / \mathrm{s}$ to $0.05 \mathrm{~kg} / \mathrm{s}$ at the solar intensity of $820 \mathrm{~W} / \mathrm{m} 2$. Indoor and outdoor evaluation is conducted to precisely evaluate the performance improvement theorized by the researcher. The comparison between the indoor and outdoor outcome purposed to confirm each testing and attraction decision. The outdoor investigation outcomes were agreement with indoor results. Indoor investigation outcomes reliably with outdoor investigation outcomes indicated by accuracy results.
\end{abstract}

This is an open access article under the CC BY-SA license.

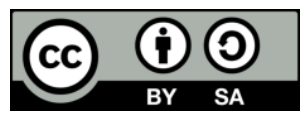

Corresponding Author:

Muhammad Zohri,

Department of Physics Education,

Universitas Islam Negeri Mataram, Indonesia.

Email: zohri.ukm@gmail.com

\section{INTRODUCTION}

The energy from fuel oil will be replaced by renewable energy in the future years. One of renewable energy is solar energy that clean, abundant and sustainable nature. Solar energy is the most critical energy source which the world requirements. Solar energy for the core application grouped into two groups. The first is to produce heat by technology solar thermal system, and the second is to generate electricity by the technology photovoltaic (PV) system. The solar thermal system applied for solar dryer and heating room system with outside voltage for pumping power. Otherwise, when photovoltaic technology system produces electricity to be able to increase the photovoltaic system temperature. The overheat of PV system decreases the electrical efficiency.

To remove the overheat from the PV system is cooled by fluids. Fluid usually used by air or water as solar heater air or water collector. Air or water heater collector passed under or up a PV system. The integrated system between the PV system and air/water heater collector is named photovoltaic (PVT) system. The PVT system produces thermal and electrical energy. PVT system can improve the cooling process of the PV system and electrical efficiency. The benefit of the PVT system reduced the space and cost requirement as related between the technology PV system and solar thermal system parted. The parameters to improve the PVT system are solar intensity, wind speed, outlet temperature, inlet temperature, the velocity of air or water collector, ambient temperature and coefficient of heat transfer [1-10].

Many researchers have conducted PVT system performances by energy and exergy analysis. Fujisawa and Tani [11] have likened performance of PVT system by yearly exergy assessment with 
horizontal-plate and solar water boiler. The photovoltaic technology thermal is integrated by monocrystalline silicon cells with and without a glazed single. Chow et al., [12] have conducted energy and exergy analysis of PVT collector glazed and unglazed shelter. Saitoh et al., [13] have integrated the PVT system based on air with a photovoltaic module and solar collector in northern Japan. The results have been compared by the energy and exergy efficiency approach monthly and detailed by Joshi and Tiwari [14]. The combination with air channel up and under the plate collector for four climates environments of five different towns of India. The PVT air collector with energetic and exergetic analysis has been conducted by Dubey et al., [15]. Nayak and Tiwari [16] have done a review of the PVT system theoretical approach. The PVT system combined photovoltaic technology and soil air boiler exchanger conservatory.

Mustapha and Aziz [17] have studied the performance of the photovoltaic pumping system for two cities in Morocco. The use of MATLAB or Simulink software established the photovoltaic pumping system simulation. The results show that the planned MPPT shows excellent performance to improve efficiency and pursuing speed. Nikita et al., [18] have estimated the electrical parameters of solar photovoltaic. Performances estimation has been compared by the NSGA-II method, and the results show that the curve parameters are suitable with the producer's datasheet. Karmila et al., [19] have analyzed the voltage constancy on the communication system with photovoltaic interconnection by power system simulator for engineering (PSSE). The simulation approach has been discussed by voltage stability indices (VSI) and previous studies. Zulkifli et al., [20] have established to maximize techniques of hybrid stand-alone photovoltaic. There are three optimizations techniques, specifically the dolphin echolocation algorithm (DEA), fast evolutionary programming (FEP), and classical evolutionary programming (CEP). The DE technique overwhelms the FE and CEF techniques.

In this study, the comparison between the indoor and outdoor investigation of PVT system solar air collector was conducted at The National University of Malaysia condition. A short-term description of indoor and outdoor evaluation has to perform. Indoor processes are performed under solar simulator with the standard testing condition (STC) where the ambient temperature, wind speed, inlet temperature, the solar intensity is controlled. The indoor investigation shows a high control variable or parameters to examine a specific effect while dependent parameters can be detained continuously. The outdoor investigation is performed in an outdoor laboratory with the following real conditions. The controlling variables while outdoor investigation processes conducted is fragile because of moving variables rapidly. However, this comparison is well to yield the actual outcome that is accurate for the customer. Photovoltaic thermal system solar air collector was planned, established and tested under indoor and outdoor investigation. This investigation aims to compare the performance of outlet temperature, photovoltaic temperature, thermal, electrical and PVT efficiency between indoor and outdoor investigation. The outdoor investigation is used to verify the rationality of indoor tested under a solar simulator.

\section{RESEARCH METHOD}

The indoor investigation constructed under solar simulator using 45 halogen lamps. And using fan DC and insulator, the photovoltaic panel of $100 \mathrm{~W}$ with monocrystalline type, flat plate as the solar collector, regulators to control solar intensity of solar simulator, Anemometer DTA 4000 to fix mass flow rate, a pyranometer to govern solar intensity and J-type thermocouple to connect ADAM-4019 and to record temperature data routinely by Solar Energy Research Institute software as shown in our manuscripts [21] and outdoor investigation has been conducted in the National University of Malaysia as shown in Figure 1. The outdoor study started from 08.00 am to $5.00 \mathrm{pm}$ for two weeks. The indoor and outdoor inquiry conducted under the solar intensity of $820 \mathrm{~W} / \mathrm{m}^{2}$ and mass flow rate from 0.01 to $0.05 \mathrm{~kg} / \mathrm{s}$. Characterization of PVT system solar air collector is measured by outlet temperature, inlet temperature, thermal efficiency, and PV efficiency. PV efficiency is contingent on its temperature. The electrical or PV energy calculated as [22-27].

$$
\eta_{P V}=\eta_{0}\left[1-0.0045\left(T_{P V}-25\right)\right]
$$

where the thermal efficiency of the PVT system solar air collector assumed as [28-33]:

$$
\eta_{t h}=\frac{\dot{m} C\left(T_{o}-T_{i}\right)}{A S}
$$

where the electrical efficiency or PV efficiency is $\eta_{P V}$, thermal efficiency is $\eta_{t h}$, the definite warmth of the air is $C$, the mass flow rates are $\dot{m}$, the solar intensity is $S$, the extent of the solar collector is $A$, outlet temperature is $T_{o}$, and inlet temperature is $T_{i}$. PV temperature is $T_{p v}$. 


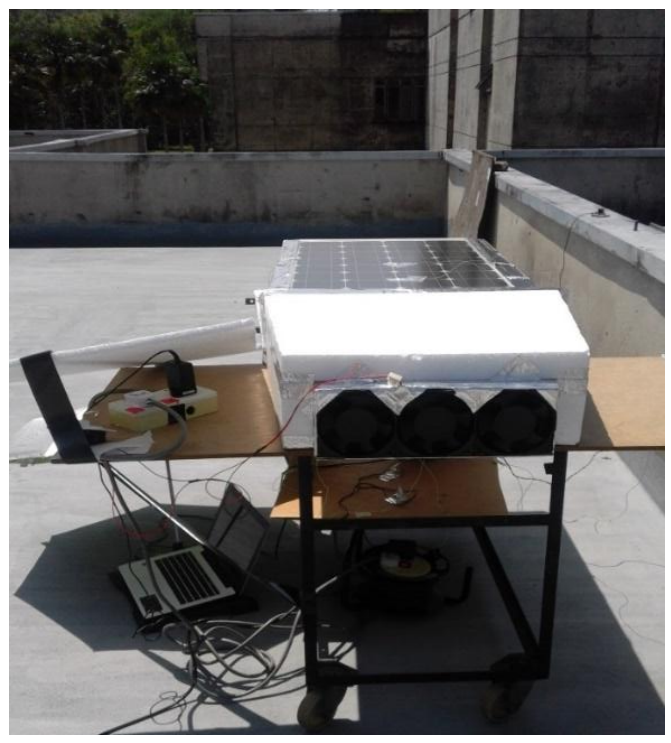

Figure 1. Outdoor experimental of photovoltaic thermal solar air collector

\section{RESULTS AND DISCUSSION}

Figure 2 displays the outlet temperature versus mass flow rate between indoor and outdoor investigation. For the indoor research, the inlet temperature is controlled average $25^{\circ} \mathrm{C}$ and solar intensity of $820 \mathrm{~W} / \mathrm{m}^{2}$. The mass flow rate is fixed from 0.01 to $0.05 \mathrm{~kg} / \mathrm{s}$. one mass flow rate is repeated for threetime minimum until one hour from stable system condition. And for outdoor investigation, the parameters are uncontrolled. We just fixed the mass flow rate from an average of $0.01-0.05 \mathrm{~kg} / \mathrm{s}$. the solar intensity is chosen an average of $820 \mathrm{~W} / \mathrm{m}^{2}$ every day with following the real system condition. The outlet temperature is recorded in computer software every minute.

The comparison outdoor and indoor investigation of PVT system air collector to expect electrical and thermal efficiency performance was showed. The performance of the thermal and electrical efficiency of the PVT system air collector was affected by the different mass flow rates with the solar intensity of $820 \mathrm{~W} / \mathrm{m}^{2}$. Figure 2 displays the PV temperature and outlet temperature that was gained by indoor and outdoor examination grades. The delivery of PV temperature and outlet temperature at the solar intensity of $820 \mathrm{~W} / \mathrm{m}^{2}$ is shown in Figure 3. Figure 2 shows that increasing the mass flow rate concurrently decreased the Photovoltaic temperature and outlet temperature of the PVT system solar air collector. The outlet temperature drops with increasing mass flow rate because the airspeed in the duct increased.

The outcomes distribution of photovoltaic temperature and outlet temperature is shown in Table 1. Outdoor outcomes confirmed the indoor investigation outcomes. The indoor outcomes investigation has controlled under solar simulator with an average error of $4.87 \%$ and $1.87 \%$ for photovoltaic temperature and outlet temperature. The indoor outcomes are reliable with outdoor results with the correctness of $95.13 \%$ and $98 \%$, correspondingly.

Figure 3 shows the temperature difference (To-Ti) versus the various mass flow rate at the solar intensity of $820 \mathrm{~W} / \mathrm{m}^{2}$. The variation mass flow rate with Indoor and the outdoor investigation conducted from 0.01 to $0.05 \mathrm{~kg} / \mathrm{s}$. $T_{o}-T_{i}$ is the temperature difference between the outlet and inlet temperature of the PVT system air collector. The maximum temperature difference is $16.77^{\circ} \mathrm{C}$ at the mass flow rate of $0.05 \mathrm{~kg} / \mathrm{s}$ with the indoor investigation. Temperature difference similarly is air temperature successfully engrossed by solar air collectors. Figure 3 displays that increasing the mass flow rate decreases the temperature difference of the PVT system solar air collector.

Figure 4 shows PV efficiency and thermal efficiency versus the mass flow rate of PVT air collectors at the solar intensity of $820 \mathrm{~W} / \mathrm{m}^{2}$. The PV efficiency maximum outcome is $14.46 \%$ at the mass flow rate of $0.05 \mathrm{~kg} / \mathrm{s}$ with an outdoor investigation outcome. The thermal efficiency maximum outcome is $84.15 \%$ at the mass flow rate of $0.05 \%$ with the indoor investigation. It showed that increasing the mass flow rate of PVT air collectors increases the PV and thermal efficiency, correspondingly.

Table 2 shows the comparison between indoor and outdoor investigation outcomes of PV and thermal efficiency with average error and accuracy approach. The average error between outdoor and indoor results is $6.78 \%$ and $9.28 \%$ for PV efficiency and thermal efficiency, correspondingly. 
The accuracy of PV efficiency and thermal efficiency is $93.22 \%$ and $90.72 \%$, respectively. From Table 2 shows that the indoor outcomes are suitable for outdoor results for PV efficiency and thermal efficiency.

Figure 5 shows PVT efficiency versus the variation of mass flow rate at the solar intensity of 820 $\mathrm{W} / \mathrm{m}^{2}$. The PVT efficiency has a similar trend with PV and thermal efficiency because the PVT efficiency is a combination of PV efficiency with thermal efficiency. The maximum PVT efficiency is $94.85 \%$ at the mass flow rate of $0.05 \mathrm{~kg} / \mathrm{s}$ with the indoor investigation. The graph trend shows that increasing the mass flow rate increase the PVT efficiency of PVT system solar collector.

Table 3 shows the evaluation of the PVT system based on air collectors between the present study and the previous study. The PV and thermal efficiency maximum are $14.46 \%$ and $84.15 \%$, respectively, for the present study. Table 3 displays that the current study results are the agreement by Slimani et al., [34], Selem et al., [35] and Fudholi et al., [21] for PV and thermal efficiency. To improve the PV and thermal energy are with growing the mass flow rate of solar air collector.

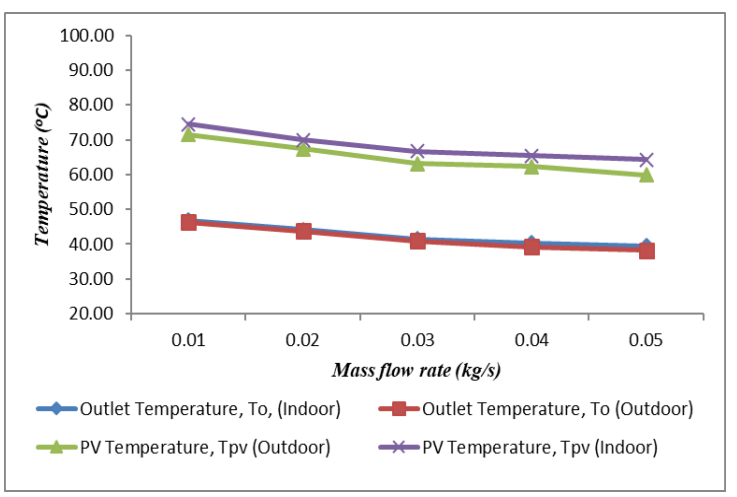

Figure 2. Outlet and PV temperature versus mass flow rates $\left(820 \mathrm{~W} / \mathrm{m}^{2}\right)$

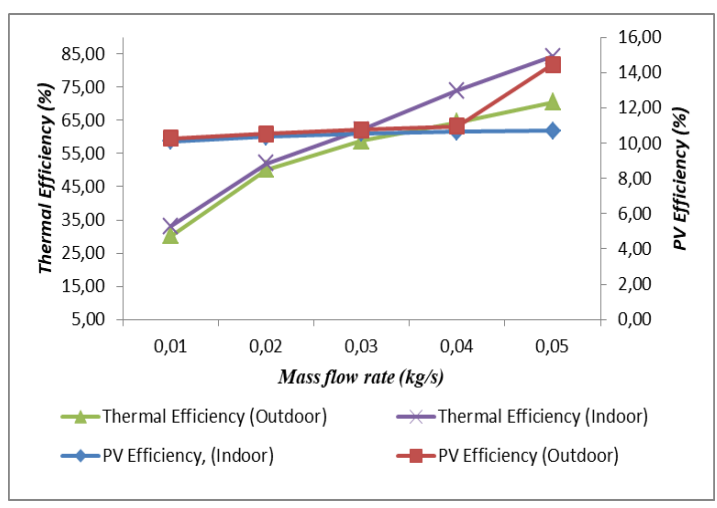

Figure 4. Thermal and PV efficiency versus mass flow rates $\left(820 \mathrm{~W} / \mathrm{m}^{2}\right)$

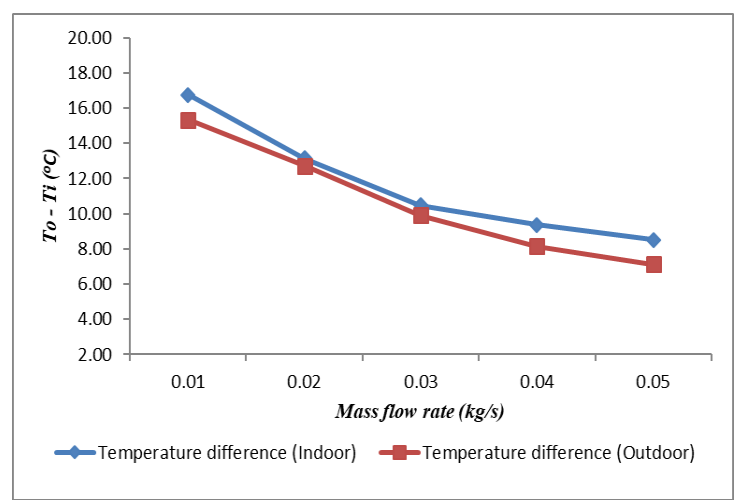

Figure 3. Temperature difference (To-Ti) versus mass flow rate at the solar intensity of $820 \mathrm{~W} / \mathrm{m}^{2}$

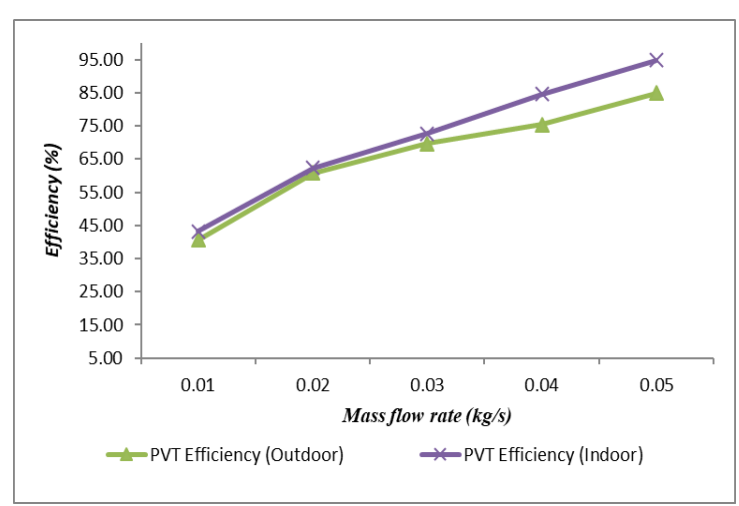

Figure 5. PVT efficiency versus mass flow rate with the indoor and outdoor investigation $\left(820 \mathrm{~W} / \mathrm{m}^{2}\right)$

Table 1. Outlet and PV temperature of PVT system solar air collector with the indoor and outdoor investigation

\begin{tabular}{cccccccc}
\hline \multirow{2}{*}{$\dot{m}(\mathrm{Kg} / \mathrm{s})$} & \multirow{2}{*}{$\mathrm{S}\left(\mathrm{W} / \mathrm{m}^{2}\right)$} & \multicolumn{3}{c}{$\mathrm{PV}$ Temperature, $\mathrm{T}_{\mathrm{c}}\left({ }^{\circ} \mathrm{C}\right)$} & \multicolumn{3}{c}{ Outlet Temperature, $\mathrm{T}_{\mathrm{o}}\left({ }^{\circ} \mathrm{C}\right)$} \\
& & Indoor & Outdoor & \% error & Indoor & Outdoor & $\%$ error \\
\hline 0.01 & 820 & 74.46 & 71.55 & 3.90 & 46.77 & 46.33 & 4.70 \\
0.02 & 820 & 69.94 & 67.41 & 3.62 & 44.13 & 43.71 & 0.61 \\
0.03 & 820 & 66.65 & 63.14 & 5.26 & 41.48 & 40.92 & 0.03 \\
0.04 & 820 & 65.35 & 62.30 & 4.67 & 40.36 & 39.14 & 2.26 \\
0.05 & 820 & 64.32 & 59.89 & 6.88 & 39.51 & 38.13 & 1.83 \\
Average & & & & 4.87 & & & 1.89 \\
\hline
\end{tabular}


Table 2. Thermal and PV Efficiency of PVT solar air collector with indoor and outdoor investigation

\begin{tabular}{cccccccc}
\hline$\dot{m}$ & \multirow{2}{*}{$\mathrm{S}\left(\mathrm{W} / \mathrm{m}^{2}\right)$} & PV efficiency $(\%)$ & \multicolumn{3}{c}{ Thermal efficiency $(\%)$} \\
$(\mathrm{Kg} / \mathrm{s})$ & & Indoor & Outdoor & \% error & Indoor & Outdoor & $\%$ error \\
\hline 0.01 & 820 & 10.11 & 10.28 & 1.65 & 33.15 & 30.31 & 8.57 \\
0.02 & 820 & 10.37 & 10.52 & 1.41 & 51.94 & 50.26 & 3.23 \\
0.03 & 820 & 10.56 & 10.77 & 1.91 & 62.16 & 58.84 & 5.34 \\
0.04 & 820 & 10.64 & 10.96 & 2.91 & 74.01 & 64.38 & 13.01 \\
0.05 & 820 & 10.70 & 14.46 & 26.02 & 84.15 & 70.49 & 16.23 \\
Average & & & & 6.78 & & & 9.28 \\
\hline
\end{tabular}

Table 3. The evaluation of PVT system design in previous studies

\begin{tabular}{clcc}
\hline References & \multicolumn{1}{c}{ Study approaches } & PV efficiency (\%) & Thermal efficiency (\%) \\
\hline$[36]$ & Experimental and theoretical & $8.3-10.4$ & $46-62$ \\
{$[37]$} & Experimental & $11.9-12.4$ & 50 \\
{$[38]$} & Experimental & 17.4 & 71.5 \\
{$[39]$} & Theoretical & 15 & 23 \\
{$[40]$} & Theoretical & $7.5-8.7$ & $51.6-52$ \\
{$[41]$} & Theoretical & $3.1-9.1$ & $32.8-41$ \\
{$[42]$} & Experimental & $\mathrm{NA}$ & 55 \\
{$[43]$} & Theoretical & 16.5 & 48 \\
{$[44]$} & Experimental and theoretical & 13.75 & 56.19 \\
{$[34]$} & Experimental and theoretical & 15 & 50 \\
{$[35]$} & Experimental and theoretical & 10.5 & 70 \\
{$[45]$} & Experimental & $17.7-38.4$ & $31.6-57.9$ \\
{$[21]$} & Experimental and theoretical & $9.87-11.34$ & $21.3-82.9$ \\
Present study & Experimental & $10.11-14.46$ & $30.31-84.15$ \\
\hline
\end{tabular}

\section{CONCLUSION}

The indoor and outdoor investigation of the PVT system air collector tested. The indoor and outdoor inquiry conducted at the National University of Malaysia. The indoor research is tested under solar simulator where the parameters are under controlled. The outdoor investigation under the sun directly is uncontrolled the parameters because of parameters actual condition. Both conditions are strengthened by another to evaluated. Indoor investigation outcomes are reliable with outdoor investigation outcomes with the correctness of $95.13 \%$ and $98 \%$ for PV and outlet temperature efficiency, correspondingly. The accuracy of PV efficiency and thermal efficiency is $93.22 \%$ and $90.72 \%$, respectively.

\section{REFERENCES}

[1] R. Kumar and M.A. Rosen, "A Critical Review of Photovoltaic-Thermal Solar Collectors for Air Heating," Applied Energy, vol. 88, no. 11, pp. 3603-3614, 2011.

[2] Y. Khanjari, F. Pourfayaz, AB. Kasaeian. "Numerical investigation on using of nanofluid in a water-cooled photovoltaic thermal system". Energy Convers Manag, vol. 122, pp. 263-78, 2016.

[3] MR. Salem MR, RK. Ali, KM. Elshazly. "Experimental investigation of the performance of a hybrid photovoltaic/thermal solar system using aluminium cooling plate with straight and helical channels". Sol Energy, vol. 157, pp. 147-56, 2017.

[4] M. Gholampour, M. Ameri, "Energy and exergy analyses of photovoltaic/thermal flat transpired collectors: experimental and theoretical study". Appl Energy, vol. 164, pp. 837-56, 2016.

[5] M. Hazami, A. Riahi, F. Mehdaoui, O. Nouicer, A. Farhat. "Energetic and exergetic performances analysis of a $\mathrm{PV} / \mathrm{T}$ (photovoltaic thermal) solar system tested and simulated under to Tunisian (North Africa) climatic conditions". Energy, vol. 107, pp. 78-94, 2016.

[6] SN. Jahromi, A. Vadiee, M. Yaghoubi. "Exergy and economic evaluation of a commercially available PV/T collector for different climates in Iran". Energy Procedia, vol. 75, pp. 444-56, 2015.

[7] P. Gang, F. Huide, Z. Tao, J. Jie, “A numerical and experimental study on a heat pipe PV/T system". Sol Energy, vol. 85, pp. 911-21, 2011.

[8] S. Agrawal, GN. Tiwari, "Energy and exergy analysis of hybrid micro-channel photovoltaic thermal module". Sol Energy, vol. 85, pp. 356-70, 2011.

[9] J. Yazdanpanahi, F. Sarhaddi, MM. Adeli. "Experimental investigation of exergy efficiency of a solar photovoltaic thermal (PVT) water collector based on exergy losses". Sol Energy, vol. 118, pp. 197-208, 2015.

[10] Shyam \& G. N. Tiwari, "Analysis of Series Connected Photovoltaic Thermal Air Collectors Partially Covered By Semitransparent Photovoltaic Module," Solar Energy, vol. 137, pp. 452-462, 2016.

[11] T. Fujisawa, T. Tani, "Annual exergy evaluation on photovoltaic-thermal hybrid collector," Solar Energy Materials and Solar Cells, vol. 47, no. 1-4, pp. 135-148. 1997.

[12] T. T. Chow, G. Pei, K. F. Fong, Z. Lin, A. L. S. Chan, J. Li, "Energy and Exergy analysis of photovoltaic-thermal collector with and without glass cover," Applied Energy, vol. 89, no. 3, pp. 310-316, 2009. 
[13] H. Saitoh, Y. Hamada, H. Kubota, M. Makamura, K. Ochifuji, S. Yokoyama, k. Nagano, "Field experiments and analyses on a hybrid solar collector," Applied Thermal Engineering, vol. 23, no. 16, pp. 2089-2105, 2003.

[14] A. S. Joshi, G. N. Tiwari, "Monthly Energy and Exergy analysis of hybrid photovoltaic thermal (PV/T) system for Indian climate," International Journal of Ambient Energy, vol. 28, no. 2, pp. 99-112, 2007.

[15] S. Dubey, S. C. Solanki, G. N. Tiwari, "Energy and Exergy analysis of PV/T air collectors connected in series," Energy and Buildings, vol. 41, no. 8, pp. 863-870, 2009.

[16] S. Nayak, G. N. Tiwari, "Theoretical performance assessment of and integrated photovoltaic and earth air heater exchanger greenhouse using energy and exergy analysis methods," Energy and Buildings, vol. 41, no. 8, pp. 888-896, 2009.

[17] M. Errouha, A. Derouich, "Study and comparison results of the field-oriented control for photovoltaic water pumping system applied on two cities in Morocco," Bulletin of Electrical Engineering and Informatics (BEEI), vol. 8, no. 4, pp. 1206-1212, 2019.

[18] N. Rawat, P. Thakur, U. Jadli., "Solar PV parameter estimation using multi-objective optimization," Bulletin of Electrical Engineering and Informatics (BEEI), vol. 8, no. 4, pp. 1198-1205, 2019.

[19] K. Kamil, M. A. A. Ab Rahman, C. K. Hen, H. Hashim, M. H. Mansor, "Analysis on the voltage stability on transmission network with PV interconnection," Bulletin of Electrical Engineering and Informatics (BEEI), vol. 8, no. 3, pp. 1162-1168, 2019.

[20] Fudholi A., Zohri M., Jin G. L., Ibrahim A., Yen C. H., Othman M. Y., Ruslan M. H., Sopian K., "Energy and exergy analyses of pho-tovoltaic thermal collector with V-groove," Solar Energy, vol. 159, pp. 742-750, 2018.

[21] Z. Othman, S. I. Sulaiman, I. Musirin, A. M. Omar, S. Shaari, "Hybrid Stand-alone Photovoltaic Systems Sizing Optimization Based on Load Profile," Bulletin of Electrical Engineering and Informatics, vol. 7, no. 2, pp. 153-160, 2018.

[22] E. Skoplaki and J. A. Palyvos, "On the temperature dependence of photovoltaic module electrical performance: A review of efficiency/power correlations," Solar Energy, vol. 83, no. 5, pp. 614-624, 2009.

[23] R. K. Agarwal and H. P. Garg, "Study of a Photovoltaic Thermal System Thermosyphonic Solar Water Heater Combined With Solar Cells," Energy Conversion and Management, vol. 35, no. 7, pp. 605-620, 1994.

[24] T. T. Chow, "A review on photovoltaic/thermal hybrid solar technology," Applied Energy, vol. 87, no. 2, pp. 365-379, 2010.

[25] M. Zohri, A. Fudholi, M. H. Ruslan, and K. Sopian, "Mathematical modeling of photovoltaic thermal PV/T system with v-groove collector," AIP Conference Proceedings, vol. 1862, no. 1, 2017.

[26] A. Fudholi, K. Sopian, M. Y. Othman, M. H. Ruslan, and B. Bakhtyar, "Energy analysis and improvement potential of finned double-pass solar collector," Energy Conversion and Management, vol. 75, pp. 234-240, 2013.

[27] M. Zohri, A. Fudholi, M. H. Ruslan, K Sopian. "Performance Analysis of Photovoltaic Thermal (PVT) with and without $\nabla$-groove Collector," Journal of Engineering and Applied Sciences, vol. 12, no. 22, pp. 6029-6032, 2017.

[28] R. K. Agarwal and H. P. Garg, "Study of a Photovoltaic Thermal System Thermosyphonic Solar Water Heater Combined With Solar Cells," Energy Conversion and Management, vol. 35, no. 7, pp. 605-620, 1994.

[29] A. Fudholi, et al., "Performance and Cost Benefits Analysis of Double-Pass Solar Collector With and Without Fins," Energy Conversion and Management, vol. 76, pp. 8-19, 2013.

[30] A. Fudholi, et al., "Collector Efficiency of the Double-Pass Solar Air Collectors with Fins," Proceedings of the 9th WSEAS International Conference on System Science and Simulation in Engineering (ICOSSSE'10), Japan, pp. 428-34, 2010.

[31] A. Fudholi, et al., "Experimental Study of the Double-Pass Solar Air Collector with Staggered Fins," Proceedings of the 9th WSEAS International Conference on System Science and Simulation in Engineering (ICOSSSE'10), Japan, pp. 410-14, 2010.

[32] A. Fudholi, et al., "Performance Analysis of Photovoltaic Thermal (PVT) Water Collectors," Energy Conversion and Management, vol. 78, pp. 641-651, 2014.

[33] A. A. El-Sebaii, S. Aboul-Enein, M. R. I. Ramadan, S. M. Shalaby, B. M. Moharram, "Thermal performance investigation of double pass finned plate solar air heater," Applied Energy, vol. 88, no. 5, pp. 1727-1739. 2011.

[34] Hazami, M., Riahi, A., Mehdaoui, F., Nouicer, O., \& Farhat, A. "Energetic and exergetic performances analysis of a PV/T (photovoltaic thermal) solar system tested and simulated under to Tunisian (North Africa) climatic conditions," Energy, vol. 107, pp. 78-94, 2016.

[35] Slimani, M. E. A., Amirat, M., Bahria, S., Kurucz, I., \& Sellami, R., "Study and modeling of energy performance of a hybrid photovoltaic/thermal solar collector: Configuration suitable for an indirect solar dryer," Energy conversion and management, vol. 125, pp. 209-221, 2016.

[36] Li, Y., Zhang, G., Lv, G. Z., Zhang, A. N., \& Wang, R. Z., "Performance study of a solar photovoltaic air conditioner in the hot summer and cold winter zone," Solar Energy, vol. 117, pp. 167-179, 2015.

[37] Good, C., Andresen, I., \& Hestnes, A. G., "Solar energy for net zero energy buildings-A comparison between solar thermal, PV and photovoltaic-thermal (PV/T) systems," Solar Energy, vol. 122, pp. 986-996, 2015.

[38] Ahn, J. G., Kim, J. H., \& Kim, J. T., "A study on experimental performance of air-type PV/T collector with HRV," Energy Procedia, vol. 78, pp. 3007-3012, 2015.

[39] Jahromi, S. N., Vadiee, A., \& Yaghoubi, M., "Exergy and economic evaluation of a commercially available PV/T collector for different climates in Iran," Energy Procedia, vol. 75, pp. 444-456, 2015.

[40] Kamel, R. S., \& Fung, A. S., "Modelling and Characterization of Transparent Building Integrated PV/T Collector," Energy Procedia, vol. 78, pp. 1871-1876, 2015.

[41] Rajoria, C. S., Agrawal, S., Tiwari, G. N., \& Chaursia, G. S., "Exergetic and enviroeconomic analysis of semitransparent PVT array based on optimum air flow configuration and its comparative study," Solar Energy, vol. 122, pp. 1138-1145, 2015.

[42] M. Gholampour and M. Ameri, "Energy and exergy analyses of Photovoltaic/Thermal flat transpired collectors: Experimental and theoretical study,” Applied Energy, vol. 164, pp. 837-856, 2016. 
[43] Rounis, E. D., Athienitis, A. K., \& Stathopoulos, T., "Multiple-inlet Building Integrated Photovoltaic/Thermal system modelling under varying wind and temperature conditions," Solar Energy, vol. 139, pp. 157-170, 2016.

[44] Mojumder, J. C., Chong, W. T., Ong, H. C., \& Leong, K. Y., "An experimental investigation on performance analysis of air type photovoltaic thermal collector system integrated with cooling fins design," Energy and Buildings, vol. 130, pp. 272-285, 2016.

[45] Salem, M. R., Ali, R. K., \& Elshazly, K. M, "Experimental investigation of the performance of a hybrid photovoltaic/thermal solar system using aluminium cooling plate with straight and helical channels," Solar Energy, vol. 157, pp. 147-156, 2017.

\section{BIOGRAPHIES OF AUTHORS}
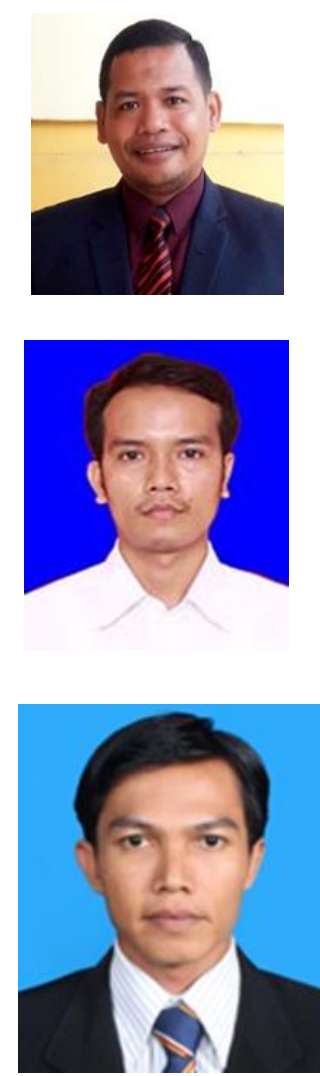

Bahtiar is currently a physic lecturer the State Islamic University (UIN) Mataram, Lombok, Indonesia. His $\mathrm{PhD}$ degree was obtained in from the State University of Surabaya, Indonesia at 2016 in the field of Physic education. He took his Master degree of Physic education at the State University of Yogyakarta. He actively researches physic and physic education. He published many articles in national and international journals. He was a speaker at MathematicInformatics-Science-Education International-Conference (MISEIC) 2017, 2018 by FMIPA State University of Surabaya and international Conference on Environmental and Science Education (ICESE) 2019 by FMIPA State University of Semarang

Muhammad Zohri obtained his S.Si (2009) in physics and received the Master of Science degree in Solar Energy Research Institute from The National University of Malaysia, Malaysia in 2017, with a thesis based on PVT system. He was appointed a graduate research assistant (GRA) under Dr Ahmad Fudholi in solar energy research institute (SERI) in UKM Malaysia, during his master's degree. He worked at Universitas Islam Negeri Mataram (UIN) Mataram, Indonesia. He was a speaker at the 2nd International Symposium on Current Progress in Mathematics and Science (2nd ISCPMS) FMIPA UI in Depok and The 4th solar energy research institute (SERI) Colloquium 2016, in UKM Bangi, Malaysia. He has published many papers in Scopus and WoS Index.

Ahmad Fudholi obtained his S.Si (2002) in physics. He has working experience about 4 years (2004-2008) as Head of Physics Department at Rab University Pekanbaru, Indonesia. A. Fudholi started his master course in Energy Technology (2005-2007) at Universiti Kebangsaan Malaysia (UKM). After his master, he became Research Assistant at UKM up to 2012. After his PhD (2012) he became Postdoctoral in Solar Energy Research Institute (SERI) UKM up to 2013. He joined the SERI as a Lecture in 2014. More than USD 304,000 research grant in 2014-2017 obtained. More than 25 M.Sc projects supervised and completed. Until now, he managed to supervise $6 \mathrm{PhD}$ (4 main supervisors and $1 \mathrm{Co}$. supervisor), 2 Master's student by research mode, and 5 Master's student by coursework mode, he was also as examiner ( $3 \mathrm{PhD}$ and 1 M.Sc). His current research focuses on renewable energy, especially energy technology. He has published more than 100 peer-reviewed papers, which 25 papers in ISI index (20 Q1, impact factor more than 3) and more than 48 papers in Scopus index, 10 more currently accepted manuscript, 20 more currently under review, and 2 book chapters. Addition, he has published more than 70 papers in international conferences. His total citations of 571 by 395 documents and h-index of 12 in Scopus (Author ID: 57195432490). His total citations of 1093 and h-index of 19 in google scholar. He is appointed as reviewer of high impact journal such as Renewable and Sustainable Energy Reviews, Energy Conversion and Management, Applied Energy, Energy and Buildings, Applied Thermal Engineering, Energy, Industrial Crops and Products, etc. He is appointed as reviewer of reputed journals such as Drying Technology, International Journal of Green Energy, Drying Technology, Biosystem Engineering, Journal of Sustainability Science and Management, Journal of Energy Efficiency, Sains Malaysiana, Jurnal Teknologi etc. He is also appointed as editor journals. He has received several awards such as Gold Medal Award at the International Ibn Al-Haytham's Al-Manazir Innovation and Invention Exhibition 2011, Silver Medal Award at the International Technology EXPO (ITEX) 2012, Silver Medal Award at the Malaysia Technology Expo (MTE) 2013, Bronze Medal Award at International Exposition of Research and Invention (PECIPTA) 2011, also 2 Bronze Medal Award at PECIPTA 2017. He was also invited as speaker: Workshop of Scientific Journal Writing; Writing Scientific Papers Steps Towards Successful Publish in High Impact (Q1) Journals 